\title{
Does spacing affect the production of clones for wood energy planted in the state of Rio Grande do Norte, Brazil?
}

\author{
O espaçamento afeta a produção de energia da madeira de clones \\ implantantados no estado do Rio Grande do Norte, Brasil?
}

\begin{abstract}
Izabelle Rodrigues Ferreira Gomes ${ }^{1}$ (i), Rosimeire Cavalcante dos Santos ${ }^{1}$ (i),
${ }^{1}$ Universidade Federal do Rio Grande do Norte - UFRN, Macaíba, RN, Brasil

2Universidade Federal de São João Del-Rei - UFSJ, Sete Lagoas, MG, Brasil

${ }^{3}$ Universidade Federal do Espírito Santo - UFES, Jerônimo Monteiro, ES, Brasil
\end{abstract} Renato Vinícius Oliveira Castro² (1) , Graziela Baptista Vidaurre ${ }^{3}$ (D), Gualter Guenther Costa da Silva1 (1), Sofia Maria Gonçalves Rocha ${ }^{3}$ (D), Cynthia Patrícia de Sousa Santos ${ }^{1}$ (D), Sarah Esther de Lima Costa ${ }^{1}$ (D), Maria Kely Alves Gomes da Silva' ${ }^{1}$, Jéssica Lamonnielly Peixoto Epifânio de Lima ${ }^{1}$ (D)

How to cite: Gomes, I. R. F., Santos, R. C., Castro, R. V. O., Vidaurre, G. B., Silva, G. G. C., Rocha, S. M. G., Santos, C. P. S., Costa, S. E. L., Silva, M. K. A. G., \& Lima, J. L. P. E., (2021). Does spacing affect the production of clones for wood energy planted in the state of Rio Grande do Norte, Brazil? Scientia Forestalis, 49(131), e3641. https://doi.org/10.18671/scifor.v49n131.25

\begin{abstract}
Silvicultural treatments can significantly influence the productivity and quality of eucalyptus wood. This work aimed to evaluate the influence of plant spacing on the production of wood and wood energy of a clone of Eucalyptus urophylla x Eucalyptus brassiana, at 4.5 years of age, planted in the state of Rio Grande do Norte, Brazil, under different spacing. The volume was measured and discs were collected from three trees, discs were collected and removed in 10 positions of each tree $(0 \%, \mathrm{DBH}, 2.5 \%, 25 \%, 37.5 \%, 50 \%, 67$, $5 \%, 75 \%, 85.5 \%$ and $100 \%$ ) in the following spacing: $3 \mathrm{~m} \times 0.5 \mathrm{~m} ; 3 \mathrm{~m} \times 1.5 \mathrm{~m} ; 3 \mathrm{~m} \times 3 \mathrm{~m} ; 3 \mathrm{~m} \times 5 \mathrm{~m}$ and $3 \mathrm{~m} \times 6.5 \mathrm{~m}$ ), totalling 15 trees and 150 discs. The wood production from 10 to 50 months of age, the basic density and energy production in the different spacing were studied. The $3 \mathrm{~m} \times 1.5 \mathrm{~m}$ spacing provided greater volumetric production and average annual increment in all evaluations, while the $3 \mathrm{~m} \times 3 \mathrm{~m}$ spacing promoted an increase in basic wood density of $10 \%$ in relation to the smallest spacing and $6 \%$ in relation to the largest spacing. For energy production, no significant difference was identified between the spacing. Thus, spacing in medium proportions are more appropriate when considering the basic density of the wood, but, if the objective is volumetric production even with smaller diameters, smaller spacing is recommended.
\end{abstract}

Keywords: Useable area; Planting density; Volumetric production; Annual increase; Caatinga.

\section{Resumo}

Os tratamentos silviculturais podem influenciar significativamente a produtividade e qualidade da madeira de eucalipto. Este trabalho teve como objetivo avaliar a influência do espaçamento entre plantas na produção de madeira e energia da madeira de um clone de Eucalyptus urophylla x Eucalyptus brassiana, aos 4,5 anos de idade, implantado no estado do Rio Grande do Norte, Brasil sob diferentes espaçamentos. Mensurou-se o volume e coletou-se discos de três árvores, foram coletados os discos foram retirados em 10 posições de cada árvore (0\%, DAP, 2,5\%,25\%, 37,5\%, 50\%, 67,5\%, 75\%, 85,5\% e 100\%) nos seguintes espaçamentos: $3 \mathrm{~m} \times 0,5 \mathrm{~m} ; 3 \mathrm{~m} \times 1,5 \mathrm{~m} ; 3 \mathrm{~m} \times 3 \mathrm{~m} ; 3 \mathrm{~m} \times 5 \mathrm{~m}$ e $3 \mathrm{~m} \times 6,5 \mathrm{~m}$ ), totalizando 15 árvores e 150 discos. Estudou-se a produção de madeira dos 10 aos 50 meses de idade, a densidade básica e produção de energia nos diferentes espaçamentos. O espaçamento $3 \mathrm{~m} \times 1,5 \mathrm{~m}$

Financial support: Nothing to declare.

Conflict of interest: Nothing to declare.

Corresponding author: izabelle.rodriguesferreira@gmail.com

Received: 25 November 2020.

Accepted: 8 April 2021.

Editor: Paulo Henrique Müller Silva.

cC) This is an Open Access article distributed under the terms of the Creative Commons Attribution License, which permits unrestricted use,

c) distribution, and reproduction in any medium, provided the original work is properly cited. 
proporcionou maior produção volumétrica e incremento médio anual em todas as avaliações, enquanto o espaçamento $3 \mathrm{~m} \times 3 \mathrm{~m}$ promoveu acréscimo em densidade básica da madeira de, 10\% em relação aos espaçamentos menores e $6 \%$ em relação aos espaçamentos maiores. Para produção de energia não foi identificada diferença significativa entre os espaçamentos. Assim, espaçamentos em proporções medianas são mais adequados quando se considera a densidade básica da madeira, mas, caso o objetivo seja a produção volumétrica mesmo com diâmetros menores, espaçamentos menores são recomendados.

Palavras-chave: Área útil; Densidade de plantio; Produção volumétrica; Incremento anual; Caatinga.

\section{INTRODUCTION}

The demand for firewood is present throughout the entire Northeast region of Brazil, in several sectors (domestic, industrial, and commercial). However, most demand comes from the industry, consuming $508.980 \mathrm{Tms} / \mathrm{year}$ according to data presented by the Northeastern Plants Association - NPA (Associação de Plantas do Nordeste, 2019). In the state of Rio Grande do Norte (RN), amongst several other activities that demand firewood, ceramics holds great importance due to its considerable contribution to the state's economy. This sector is highly dependent on firewood, which is used to supply the kilns responsible for the consumption of this material. A good portion of the firewood utilized is extracted from native forests (Chavez, 2016).

According to Gariglio (2010) the Ministry of the Environment - ME, $47.6 \%$ of firewood used as an energy source in RN goes to the industry, and $53.4 \%$ is used by the domestic sector. However, most of the forest exploitation is completely unplanned. This results in accelerated deforestation of the Caatinga (xeric shrubland) region and endangers its biodiversity, and the potential of its natural resources. Gariglio (2010), noted that 59\% of all firewood consumed in the Caatinga comes from illegal logging.

In Brazil, the genus Eucalyptus has the potential for increasing wood production for many uses, including as an energy source. This potential comes from the adaptability this genus presents to different soil and climatic conditions in the country, and also from its rapid growth. Numerous researches and improvement programs were started in order to generate genetically superior individuals (Vakkilainen et al., 2013). In the state of Rio Grande do Norte (RN) there are no relevant records of any research shedding light on the viability of this genus for wood as an energy source; however the state is highly dependent on this fuel.

For afforestation one must consider the effect spacing has on volumetric production and wood quality. Forestry companies seek to increase wood production per area, attempting to identify for management regimes the technique that generates the highest quality of the final product.

Among the several conditioning factors of forest production, spacing has a fundamental role in its establishment, on forest supervision and production costs, since it can have an influence on the trees' growth rates, on wood quality, cutting age, as well as on implementation practices, management and harvesting (Ribeiro, 2016).

Thus, one way to reduce the pressure on the Caatinga biome is to indicate to the industrial sector an alternative of wood use from an exotic forest species as an energy source - a species that displays quick growth and high adaptability to various conditions of Brazil, thereby addressing environmental, social, and economic issues of wood commercialization in the state.

This search aimed to evaluate the influence of five different spacings on the energy production from the wood of a clone Eucalyptus urophylla $x$ Eucalyptus brassiana, 4.5 years old, planted in the state of Rio Grande do Norte, Brazil. 


\section{MATERIALS AND METHODS}

\subsection{TECHS Project}

This study is part of the international experimental project network, TECHS (Tolerance of Eucalyptus Clones to Hydric and Thermal Stresses). The project aims to investigate eucalyptus growth throughout the climatic gradient comprised by Brazil and northern Uruguay. The project started in 2011 and its main purpose is to understand and quantify how the climate limits eucalyptus' clonal production (Binkley et al., 2017).

\subsection{Area of study and characteristics of the experiment}

The study was set up in a forest experimentation area located in the town of Macaíba/RN, during the dry season, with different planting densities as a variation factor, described in Figure 1. Among 10 clones, the hybrid clone Eucalyptus urophylla $\times$ Eucalyptus brasianna was selected as the object this study.

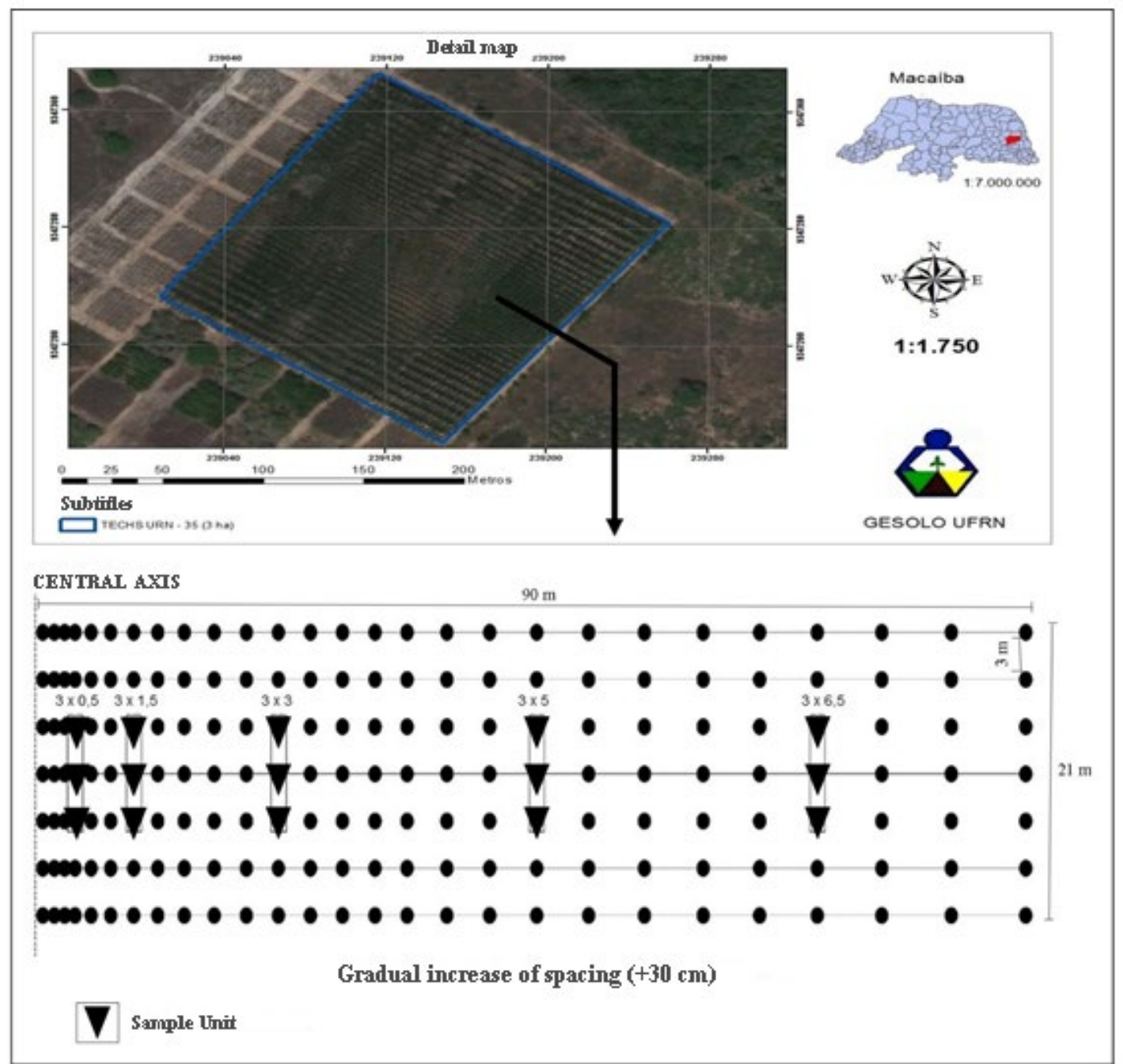

Figure 1. TECHS URN - 35 Trial design, located in Macaíba/RN (top portion) with 10 clones. Each clone occupies an experimental plot of 7 rows and 27 spacing between trees inside the rows. Arrangement of the trees in the experimental plot, which were studied with the Eucalyptus urophylla $x$ Eucalyptus brassiana clone (bottom portion)

The town of Macaíba/RN was included in the new semiarid delimitation proposed by the Superintendence of North-eastern Development (Superintendência do Desenvolvimento do 
Nordeste - SUDENE) since November of 2017 (Superintendência do Desenvolvimento do Nordeste, 2017). The meteorological data for the period was obtained from the pluviometry installed near the experiment, in Macaíba - RN (rainfall), in which the data which was gathered on an hourly basis, was transformed into a daily scale. This process was carried out according to the precepts for filling gaps in meteorological spreadsheets proposed by Rocha, 2020.

Monthly data are presented by year, for rainfall and temperature in Macaíba/RN for the period from 2014 to 2018 (Figure 2)

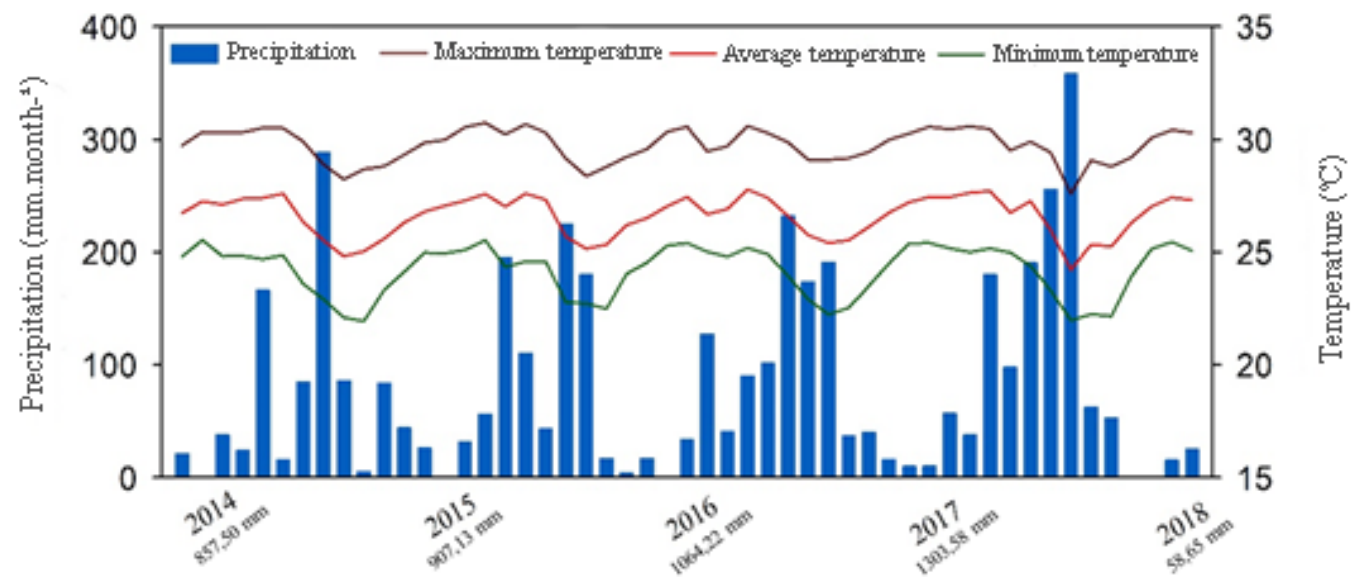

Figure 2. Rainfall data ( $\mathrm{mm} / \mathrm{month}$ ) and Temperature ${ }^{\circ} \mathrm{C}$ for Macaíba/RN, and Temperature $\left({ }^{\circ} \mathrm{C}\right)$ for Macaíba in the period between January of 2014 and January of 2018

Although the average, maximum and minimum temperatures are high throughout the year, the average annual rainfall of $1,044.61 \mathrm{~mm}$ at -1 is relatively high (Figure 2) when compared to other locations in Brazil in the same period (Rocha et al., 2020). The rainfall is seasonal throughout the year in all four years. In the first quarter, it rains less, while in the second quarter it rains more, followed again by periods of drought. The region's climate is classified as semi-arid (BSh) according to the Köppen climate classification (Alvares et al., 2013).

The soil in the area is an oxisol ("Latossolo Amarelo" - Yellow Latosols) of sandy texture, and the topography is flat. Two fertilizations were applied. Gypsum was spread at 2,000 kg ha ${ }^{-1}$. Afterwards, ploughing was done on the planting line with fertilized with N-P-K (06-36-06) at $350 \mathrm{~kg} \mathrm{ha}^{-1}$. Fertilizing was carried out through side dressing with $100 \mathrm{~g} \mathrm{plant}^{-1}(6-36-6)$ and the application within the crown projection (April/2014) of $400 \mathrm{~kg} \mathrm{ha}^{-1}$ of N-P-K (14-36-14). At the same time $150 \mathrm{~kg} \mathrm{ha}^{-1}$ of FTEBR12 micronutrients were applied.

The trial design adopted for implementing the experiment was systematic, with a continuous quantitative factor, adapted to Nelder's (1962) proposal. The systematic designs of continuous quantitative factor are those in which the treatments represent increasing doses or values of a certain factor and are arranged in the experimental units in increasing or decreasing order, based on the experimental area's homogeneity and low correlation between neighbouring sites. The tree planting was linear, with a gradual increase in spacing between the trees, maintaining a constant distance of $3 \mathrm{~m}$ between the rows.

For this study, wood from 15 trees of the hybrid E. urophylla $x$ E. brassiana was examined. Disregarding two border rows of each side, the useable area for this study was composed of 3 rows, 24 plants each, and 5 plant spacing were examined as a source of variability.

To quantify the mortality in each spacing, the data obtained through the Forest Census in the $53^{\text {th }}$ month ( 4.5 years of age) were used. The diameter at breast height (DBH) was measured for all trees at the site using a tape measure. Height (h) was measured with the aid of an analog hypsometer and the count of dead trees. 


\subsection{Wood sampling and sample preparation}

In order to carry out the studies of the technological characteristics and production of wood energy, given that the variability of basic density is low, being an inherited characteristic, the sample was taken from a selection of three trees spaced differently in the plantation. Disks in ten different positions on the trunk were taken from these trees, longitudinally, as follows: $0 \%$ - base; $\mathrm{DBH} ; 12.5 \% ; 25 \% ; 37.5 \% ; 50 \% ; 67.5 \% ; 75 \% ; 87.5 \%$ and $100 \%$ of the commercial height of the tree up to a diameter of 5 centimeters.

\subsection{Calculating wood properties and wood energy production in each spacing evaluated}

Basic density of the wood was calculated based on the arithmetic mean of the densities from the respective wedges along the trunk. This follows the norm NBR 11941 from the Brazilian Association of Technical Norms (Associação Brasileira de Normas Técnicas, 2003).

The wood's high calorific value was calculated following the regulatory standard D201596 (American Society for Testing and Materials, 2015). The material was macerated on the Wiley mill, then sifted through 40 and 60 screens, utilizing what was left of the latter. The analyses were performed using each spacing examined.

The volumetric production of wood was obtained in each treatment every six months, totalling six times, by cubing of 3 sample trees at 4.5 years of age. Strict cubing consisted of slicing the stems into several parts and measuring them individually. After calculating the volume of these parts, they were added to obtain the total bole, according to the method of Smalian (Soares et al., 2011) according to the equation:

$V i=\frac{A S_{1}+A S_{2}}{2} * L$

In which: $A S_{1}$ and $A S_{2}$ are the sectional areas obtained from the edges of each section in $\mathrm{m}^{2}$, and $L$ is the section's length.

The volume of each tree was obtained through the sum total of the individual volumes according to the equation:

$V=\sum V i$

After calculating the real volume $(V)$, the average form factor $(f)$ for each treatment was calculated according to the equation:

$f=\frac{V_{\text {real }}}{\text { Vcylinder }}$

In which: $f$ corresponds to the form factor; $V_{\text {real }}$ is the true volume of the tree and $V_{\text {cylinder }}$ is the volume of a cylinder of equal diameter at DBH of the measured tree.

In order to estimate the real wood volume in each experimental tree, a methodology proposed by Soares et al. (2011) was applied according to the equation:

$V=\frac{\pi D B H^{2}}{4} H \bar{f}$

In which: $V$ is the volume of a tree's stem; DBH refers to the diameter at breast height $(1.30 \mathrm{~m})$; $\mathrm{H}$ is height in meters; $\bar{f}$ is the average form factor. Afterwards, the volume of the surviving trees was summed and the production of each treatment was extrapolated to a hectare.

Dividing the production by age gives us the mean annual increment (MAl) in $\mathrm{m}^{3} \mathrm{ha}^{-1} \mathrm{y}^{-1}$. For each spacing, the dry mass of wood, referring to basic density $\left(\mathrm{kg} \mathrm{m}^{-3}\right)$, was multiplied by its high calorific value $\left(\mathrm{kcal} \mathrm{kg}^{-1}\right)$ in order to obtain wood energy production values in $\mathrm{kcal} \mathrm{m}^{-3}$. The energy produced by cubic meter of wood $\left(\mathrm{kcal} \mathrm{m}^{-3}\right)$ was multiplied by the average productivity of each species $\left(\mathrm{m}^{3} \mathrm{ha}^{-1}\right)$ in order to obtain the result in $\mathrm{kcal} \mathrm{ha}^{-1}$, according to the methodology utilized by Santos et al. (2011). 


\subsection{Statistical data analysis}

Data on each variable was submitted to the Kolmogorov-Smirnov's test and Lilliefors' test to evaluate normality and homogeneity of the variances, respectively. Then, variance analysis through the $\mathrm{F}$ test was performed and the averages compared through the Tukey test at 5\% significance for all analyses. For the variables which did not meet the requirements of the variance analysis, the Kruskall-Wallis' nonparametric test was used. The statistical analysis was conducted with the assistance of the R software, version 2.13 1.

\section{RESULTS AND DISCUSSION}

Larger spacing favoured an increase in the basic density of the wood, even though spacing $3 \mathrm{~m} \times 5 \mathrm{~m}$ and $3 \mathrm{~m} \times 6.5 \mathrm{~m}$ did not differ statistically from spacing $3 \mathrm{~m} \times 3 \mathrm{~m}$, the latter being the largest average basic density found. Spacing $3 \mathrm{~m} \times 0.5 \mathrm{~m}$ and $3 \mathrm{~m} \times 1.5 \mathrm{~m}$ showed significant statistical differences when compared to $3 \mathrm{~m} \times 3 \mathrm{~m}$. However, they did not differ statistically from each other (Figure 3)

We did not find statistical variations at different spacing on the average high calorific values from the wood of the clone studied (Figure 3). Spacing had a significant effect on the amount of the clone's wood energy (Figure 3), in such a way that a higher average value of this variable was observed in trees with spacing $3 \mathrm{~m} \times 3 \mathrm{~m}$.
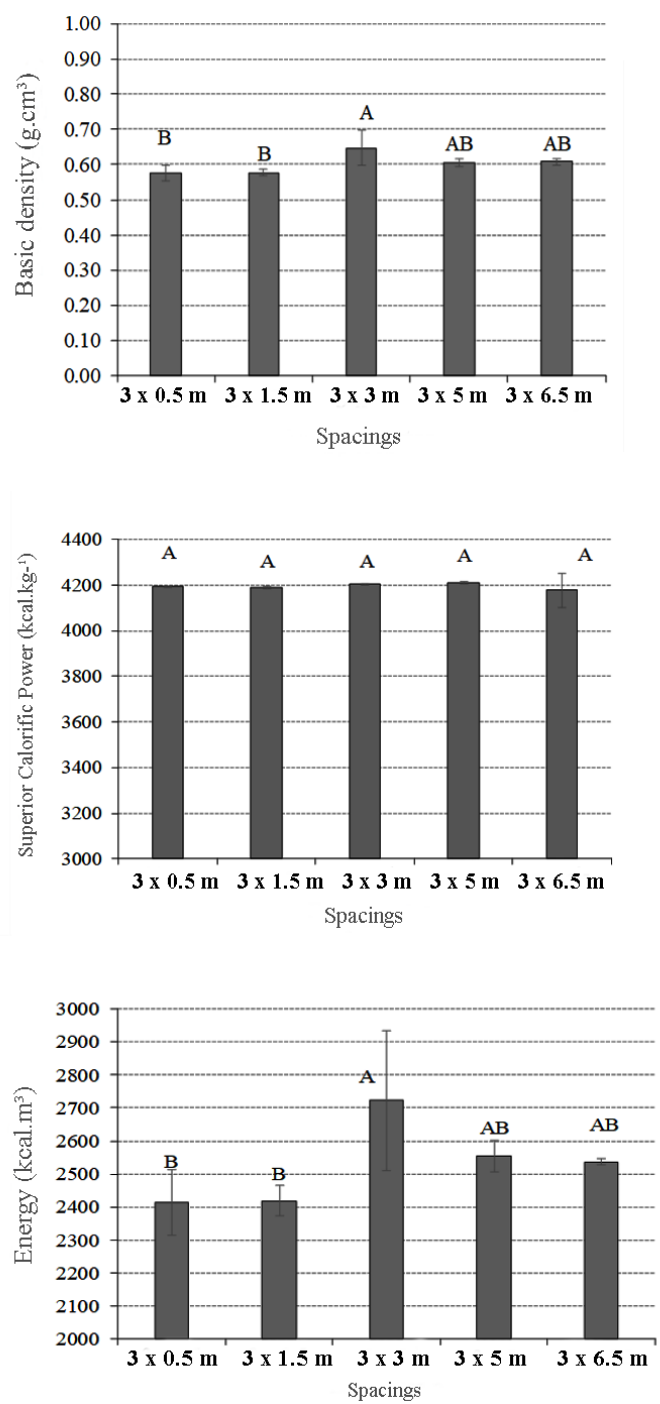

Figure 3. Effect of plant spacing over basic density $\left(\mathrm{g} \mathrm{cm}^{-3}\right)$, high calorific value $\left(\mathrm{kcal} \mathrm{kg}^{-1}\right)$ and energy $\left(\mathrm{kcal} \mathrm{m}^{-3}\right)$ of the clone E. urophylla $\times$ E. brassiana 
It was found that plant mortality (Table 1) varied at different spacing, with a higher mortality percentage found with the denser spacing $(3 \mathrm{~m} \times 0.5 \mathrm{~m})$.

Table 1. Mortality percentage of the hybrid E. urophylla x E. brassiana, at 54 months, at different spacings, on RN's coastal region

\begin{tabular}{ccc}
\hline Treatment $(\mathbf{m})$ & Density (trees/ha) & Mortality (\%) \\
\hline $3 \times 0.5$ & 6667 & 20 \\
$3 \times 1.5$ & 2222 & 8 \\
$3 \times 3$ & 1111 & 0 \\
$3 \times 5$ & 667 & 0 \\
$3 \times 6.5$ & 513 & 0 \\
\hline
\end{tabular}

This indicates that smaller spacing provides an increase in the percentage of mortality, even though an increase in the volumetric production of wood per hectare was expected.

Between 10 and 30 months, the spacing $3 \mathrm{~m} \times 0.5 \mathrm{~m}$ and $3 \mathrm{~m} \times 1.5 \mathrm{~m}$ showed similar responses in volumetric production per hectare. They were, however, followed by a decline compared to those spaced more densely. The largest volumetric production of wood per hectare was found at spacing $3 \mathrm{~m} \times 1.5 \mathrm{~m}$ and $3 \mathrm{~m} \times 3 \mathrm{~m}$.

The mean annual increase is influenced by the different spacing. The smaller spacing show the highest values (Figure 4). Spacing $3 \mathrm{~m} \times 3 \mathrm{~m}$ surpasses all others when considering energy production (Figure 4). The higher competition and mortality of trees in the spacing $3 \mathrm{~m} \times 0.5 \mathrm{~m}$ probably influenced the lower energy production despite the higher planting density.
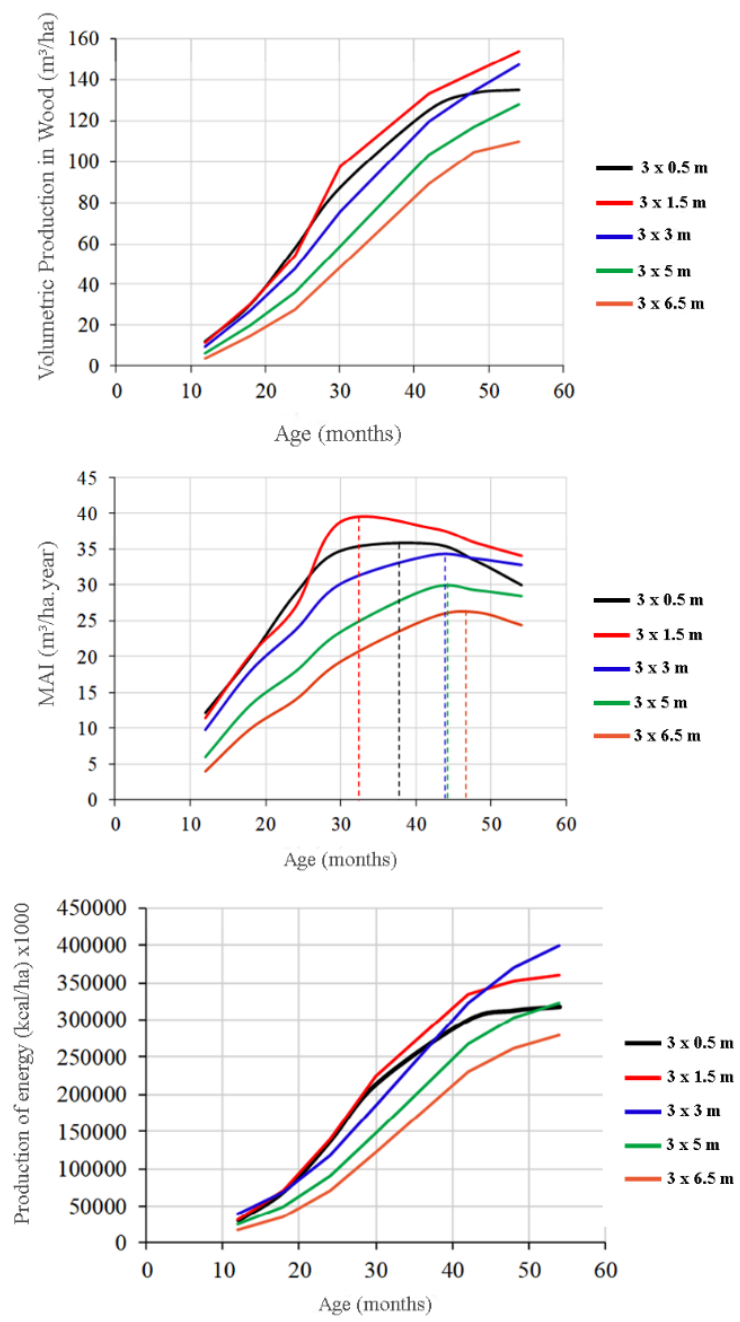

Figure 4. Volumetric production of wood $\left(\mathrm{m}^{3} \mathrm{ha}^{-1}\right)$, mean annual increment $\left(\mathrm{m}^{3} \mathrm{ha}^{-1} \mathrm{y}^{-1}\right)$, and energy

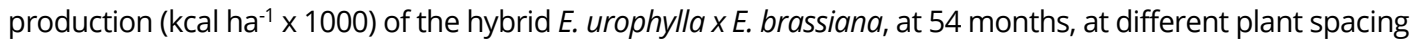


The results obtained in the study suggest that the greater averages in basic density are found in the wider spacing in the planting. This result can be explained by the better growing conditions provided by the spacing. The results obtained in this study suggest that greater averages of density are found in broader spacing. Broader spacing collaborates to reduce competition between the trees, which present greater production of photo-assimilates and contribute to greater basic density in the wood. Possibly, the reduction of basic density in the narrower spacing ( $3 \mathrm{~m} \times 0.5 \mathrm{~m}$ e $3 \mathrm{~m} \times 1.5 \mathrm{~m}$ ) occurred in response to the stagnation in growth occasioned by exhausting water resources and nutrients in the soil.

Thus, an increase in growth is directly related to the physiological activity of the vascular exchange, which under favorable conditions provides the formation of a cell wall of greater mass per unit of volume, due to the wider spacing between the trees (Evert, 2006). The greatest average basic density was found in the spacing $3 \mathrm{~m} \times 3 \mathrm{~m}$ in E. grandis $\times$ E. camaldulenses, at 85 months old (Rocha et al., 2018). This can be attributed to the favorable growth conditions when there is little or no competition for water, light and nutrients. Thus, the plant increases the capacity to store carbon, absorb it from the atmosphere, and fix it in the form of cellulose (Souza et al., 2008).

Larger planting spacing ( 9 and $12 \mathrm{~m}^{2}$ ) also resulted in larger trunk diameters and basic wood density in E. grandis and E. urophylla clones (Brito et al., 2021). This author attributes it to a greater increase in thickness of the cell wall of the clones, which possibly took advantage of the greater availability of nutrients for synthesis of the increment of the cell wall.

However, the sites presented in this study are sites that present more clayey soils and with greater availability of organic matter, differently from the soils of the caatinga, but, even with this limitation the increase in useful space, from $9 \mathrm{~m}^{2}$ onwards resulted in the largest increase in basic wood density.

No significant difference could be verified between different spacing on the wood's basic density in E. urophylla $\times$ E. grandis at 12 months. This result may be due to the fact that the forest was recently planted, even though a tendency of the smaller spacing to show higher basic density values has been observed (Sereguetti et al., 2015).

Upon examining the basic density in Eucalyptus grandis a decrease in density with the increase of spacing was observed, at 12 plant spacing with an average age of 10 years (Goulart et al., 2003). Thus, although a general tendency relating spacing to basic density was not observed, these responses suggest some influence on wood growth and quality depending on the demand and its commercial use.

When producing energy wood, the spacing $3 \mathrm{~m} \times 3 \mathrm{~m}$ seems ideal considering the wood's high basic density (Figure 3). This is due to the fact that high basic density values are recommended for better energy production, and this property is directly associated with dry biomass production (Neves et al., 2013).

The spacing of the planting does not affect the higher heating power of the 48-month-old wood (Figure 3). However, with the increase in spacing the trees tend to grow taller, which results in trees with a greater portion of juvenile wood and thus, greater lignin content. This affects the SHP directly, as it is related to the chemical constitution of the wood, mainly the extractives and lignin (Rocha et al., 2018).

Higher calorific values lead to less carbon consumption for the same productivity, and guarantees higher quantity of heat produced during combustion for the same volume of charcoal (Protásio et al., 2011; Neves et al., 2011). However, a species' superiority over other species in energy production is related mainly to the higher biomass production, since the difference in calorific value is low or nonexistent (Eloy et al. 2015). This characteristic must be evaluated together with the productivity in firewood, given that if there is quality but no productivity, the financial viability of the undertaking as a source of energy can be compromised (Lima et al., 2013).

Results similar to the basic density values were found for the energy value of the wood, especially in spacing $3 \mathrm{~m} \times 3 \mathrm{~m}$ (Figure 3). This was expected given that basic density is included when calculating energy value. Thus, higher basic density values indicate higher energy values 
due to a higher quantity of dry mass per volume unit. This means a larger quantity of fuel for burning, which was the parameter used for the quality of the raw material.

For the clone E. grandis $x$ E. camaldulensis it was found that when the spacing between trees was reduced, energy values per hectare/year increased (Rocha et al. 2018). This can be explained mainly by higher values of dry mass obtained from the smaller spacing. Understanding the effect of different spacing on energy production is an essential tool of forest planning. It implies cost reduction for plant implementation and management.

Larger plant spacing indicate a smaller number of plants per hectare. Adopting a larger spacing such as $3 \mathrm{~m} \times 5 \mathrm{~m}$ and $3 \mathrm{~m} \times 6.5 \mathrm{~m}$ may not be a viable alternative for the industry due to smaller energy production per hectare. Moreover, the increase in spacing examined led to smaller basic density values than at spacing $3 \mathrm{~m} \times 3 \mathrm{~m}$ as did the energy production in this clone.

The wood production result (Figure 4) occurred because denser spacing caused more competition for water, light, and nutrients. This leads to suppression and death of the less favored trees. This also explains the reduction of the production parameter in wood volume, as can be seen after 40 months of age in trees at $3 \mathrm{~m} \times 0.5 \mathrm{~m}$. In denser forest populations, the higher proximity of the root systems intensifies the competition, affecting the diametric growth of the plants (Stape et al., 2010). In less dense populations the survival rate reaches $100 \%$ due to spacing having low or no effect on this parameter.

On the other hand, at $3 \mathrm{~m} \times 1.15 \mathrm{~m}$ the volume productivity in wood was superior to other treatments as shown in Figure 4. This result may have been due to the fact that this treatment resulted in a usable area sufficient enough for the competition between trees not to interfere with growth. In addition there was a larger quantity of trees per hectare. In spite of having less competition in spacing $3 \mathrm{~m} \times 5 \mathrm{~m}$ and $3 \mathrm{~m} \times 6.5 \mathrm{~m}$, the number of trees is smaller under those conditions. Thus, these results were less expressive for the wood volume production parameter. In addition, the favorable results of spacing $3 \mathrm{~m} \times 3 \mathrm{~m}$ were most likely due to the trees' growth in diameter.

In denser plantings, the number of trees is higher than in the larger spacing. Despite the competition between trees, the wood volume is higher. This contributes to the increase in dry mass, and consequently the increase in wood volumetric production (Moulin et al., 2017). However, economic analysis on the implementation, maintenance, harvest, and forest transportation costs must be done in order to verify the viability of the dense planting projects. This analysis will tell if the revenue obtained with dry mass in the biomass surpasses the expenses with the mentioned costs.

The larger wood production per hectare was influenced by the spacing, and, consequently, energy production (Figure 4); as the biomass is reduced with the increase in vital space (Goulart et al., 2003). This shows the importance of volumetric productivity and basic density, given that the variable is a direct function of these two parameters.

Certainly, this is correlated to the larger values of basic density (Figure 3) found in trees under this density condition. This interferes directly with the higher quantity of carbon deposited on the trees' trunk. Their energy production per hectare ends up being greater as well. The carbon concentration is important when the wood is utilized for energy generation, both as raw material for charcoal production as well as by directly burning the wood as fuel, since the fuel material available for combustion increases in a direct proportion to the carbon percentage present in the stem (Carneiro et al., 2014).

It is worth mentioning that in smaller spacing the number of trees is greater than in the larger ones, and even with competition between trees and higher mortality rate, the wood volume is greater. This contributes to the increase in dry mass, and consequently in average values of stored energy (Rocha et al., 2020).

In less dense spacing, the growth space for each tree is broadened, thereby providing better growth and development for the plant, and larger diameters, higher conic shape, and a good root and crown development. These characteristics contribute directly to the quality and quantity of individual production (Lima et al., 2013). 
MAI can indicate the optimal cutting age when the forest reaches the maximum volume per hectare. In this case, for the studied clone, this occurs between 30 and 40 months. This is the moment of maximal productive capacity. Pruning is recommended until this age, considering that we will be extracting the greatest possible volume on average along several forest rotations. In some cases, the interest is in the volumetric production (energy). In other cases, trees of a larger diameter are preferred (timber and woodworking).

\section{CONCLUSIONS}

The spacing affected the growth in volume per $\mathrm{m}^{3}$ and hectare of a clone Eucalyptus urophylla x Eucalyptus brassiana. It also affected the evolution of annual increases of this variable. Denser spacing presented higher annual increases in volume per area unit. The difference between spacing confirms the tendency of higher annual increases in volume due to less vital space available. Additionally the spacing $3 \mathrm{~m} \times 3 \mathrm{~m}$ favored the increase in basic density and wood volumetric production, thus, for the conditions evaluated, this spacing is the most suitable for wood production designated for generating energy.

The development of the clone in the region can be considered good, depending on a good distribution of rainfall during the year. Smaller spacing are recommended when the objective is volumetric production in spite of the smaller diameters obtainde. For trees of larger diameters, wider spacing is a better option.

\section{ACKNOWLEDGMENT}

Forest Research and Studies Institute (IPEF), Federal University of Rio Grande do Norte (UFRN) and Federal University of Espírito Santo (UFES).

\section{REFERENCES}

Alvares, C. A., Stape, J. L., Sentelhas, P. C., Gonçalves, J. D. M., \& Sparovek, G. (2013). Köppen's climate classification map for Brazil. Meteorologische Zeitschrift (Berlin), 22, 711-728.

American Testing And Materials Society - ASTM (1996). D2015-96: wood-determining the high calorific value of wood. West Conshohocken: ASTM.

Associação Brasileira De Normas Técnicas - ABNT (2003). NBR-11941: madeira - determinação da densidade básica. Rio de Janeiro: ABNT.

Associação De Plantas do Nordeste - APNE (2019) Oferta de biomassa renovável para os pólos cerâmicos do Nordeste do Brasil. Recife: APNE.

Binkley, D., Campoe, O. C., Alvares, C., Carneiro, R. L., Cegatta, Í., \& Stape, J. L. (2017). The interactions of climate, spacing and genetics on clonal Eucalyptus plantations across Brazil and Uruguay. Forest Ecology and Management, 405, 271-283.

Brito, A. S., Vidaurre, G. B., Oliveira, J. T. S., Silva, J. G. M., Oliveira, R. F., Dias Junior, A. F., Arantes, M. D. C., Moulin, J. C., Valin, M., Siqueira, L., \& Zauza, E. A. V. (2021). Interaction between planting spacing and wood properties of Eucalyptus clones grown in short rotation. iForest Biogeosciences and Forestry, 14, 12-17.

Chaves, A. G. C. (2016). Diagnóstico da exploração de lenha em planos de manejo sustentável na caatinga do Rio Grande do Norte. (Dissertação de mestrado). Natal.

Carneiro, A. C. O., Castro, A. F. N. M., Castro, R. V. O., Santos, R. C., Ferreira, L. P., Damásio, R. A. P., \& Vital, B. R. (2014). Potencial energético da madeira de Eucalyptus sp. em função da idade e de diferentes materiais genéticos. Revista Árvore, 38, 375-381.

Eloy, E., Caron, B. O., Silva, D. A., Souza, V. Q., Trevisan, R., Behling, A., \& Elli, E. F. (2015). Produtividade energética de espécies florestais em plantios de curta rotação. Ciência Florestal, 45, 1424-1431.

Evert, R. F. (2006). Esau's plant anatomy (3rd ed.). New Jersey: Wiley-Inter Science.

Gariglio, M. A., Sampaio, E. D. S., Cestaro, L. A., \& Kageyama, P. Y. (Eds.). (2010). Uso sustentável e conservação dos recursos florestais da caatinga. Brasília, DF: Serviço Florestal Brasileiro.

Goulart, M., Haselein, C. R., Hoppe, J. M., Farias, J. A., \& Pauleski, D. T. (2003). Massa especifica básica e massa seca de madeira de Eucalyptus grandis sob o efeito do espaçamento de plantio e da posição axial no tronco. Ciência Florestal, 13, 167-175. 
Lima, R., Inoue, M. T., Figueiredo Filho, A., Araujo, A. J., \& Machado, S. A. (2013). Effect of spacing on the volumetric development of Pinus taeda L. Floresta e Ambiente, 20, 223-230.

Moulin, J. C., Arantes, M. D. C., Oliveira, J. G. L., Campinhos, E., Gomes, F., \& Vidaurre, G. B. (2017). Effect of spacing, age and irrigation on the volume and basic density in Eucalyptus. Floresta e Ambiente, 24 e00073914.

Nelder, J. A. (1962). New kinds of systematic designs for spacing experiments. Biometrics, 18, 283-307.

Neves, T. A., Protásio, T. P., Couto, A. M., Trugilho, P. F., Silva, V. O., \& Vieira, C. M. M. (2011). Avaliação de clones de Eucalyptus em diferentes locais visando à produção de carvão vegetal. Pesquisa Florestal Brasileira, 31, 319-330.

Neves, T. A., Protásio, T. P., Trugilho, P. F., Valle, M. L. A., Sousa, L. C., \& Vieira, C. M. M. (2013). Qualidade da madeira de clones de Eucalyptus em diferentes idades para a produção de bioenergia. Revista de Ciências Agrária, 56, 139-148.

Protásio, T. P., Santana, J. D. P., Neto, R. M. G., Júnior, J. B. G., Trugilho, P. F., \& Ribeiro, I. B. (2011). Avaliação da qualidade do carvão vegetal de Qualea parviflora. Pesquisa Florestal Brasileira, 31, 295-307.

Ribeiro, G. B. D., Valverde, S. R., (2016). Breve elucidação sobre os leilões de energia e o potencial da biomassa florestal. Revista Madeira, 43-45.

Rocha, M. F. V., Pereira, B. L. C., Oliveira, A. C., Pego, M. F. F., Veiga, T. R. L. A., \& Carneiro, A. C. O. (2018) Influence of plant spacing on the bark properties of a Eucalyptus clone. Revista Árvore, 42, e420501.

Rocha, S. M. G., Vidaurre, G. B., Pezzopane, J. E. M., Almeida, M. N. F., Carneiro, R. L., Campoe, O. C., Scolforo, H. F., Alvares, C. A., Neves, J. C. L., Xavier, A. C., \& Figura, M. A. (2020). Influence of climatic variations on production, biomass and density of wood in eucalyptus clones of different species. Forest Ecology and Management, 473, 118290.

Sereguetti, G. C., Lanças, K. P., Sartori, M. S., Rezende, M. A., \& Soler, R. R. (2015). Efeito do espaçamento no crescimento e na densidade básica da madeira de Eucalyptus urophylla $\times$ Eucalyptus grandis em florestas de ciclo curto. Revista Energia na Agricultura, 30, 257-262.

Santos, R. C., Carneiro, A. D. C. O., Castro, A. F. M., Castro, R. V. O., Bianche, J. J., de Souza, M. M., \& Cardoso, M. T. (2011). Correlation of quality parameters of wood and charcoal of clones of eucalyptus. Sci. For., 39, 221-230

Soares, C. P. B., Martins, F. B., Leite Junior, H. U., Silva, G. F., \& Figueiredo, L. T. M. (2011). Equações hipsométricas, volumétricas e de TAPER para onze espécies nativas. Revista Árvore, 35(5), 1039-1053.

Souza, G., Gaspar, M., Tiné, M. A. S., \& Buckeridge, M. S. (2008). Ajustando os botões: como as plantas lidam com o aumento do $\mathrm{CO}_{2}$ atmosférico. In M. S. Buckeridge (Ed.), Biologia e mudanças climáticas no Brasil (Vol. 6, pp. 101-113). Rima.

Stape, J. L., Binkley, D., Ryan, M. G., Fonseca, S., Loos, R. A., Takahashi, E. N., Silva, C. R., Silva, S. R., Hakamada, R. E., Ferreira, J. M. A., Lima, A. M. N., Gava, J. L., Leite, F. P., Andrade, H. B., Alves, J. M., \& Silva, G. G. C. (2010). The Brazil eucalyptus potential productivity project: influence of water, nutrients and stand uniformity on wood production. Forest Ecology and Management, 259, 1684-1694.

Superintendência do Desenvolvimento do Nordeste - SUDENE. (2017). Delimitação do semiárido. Retrieved in 2019, May 9, from http://www.sudene.gov.br/planejamento-regional/delimitacao-dosemiarido

Vakkilainen, E., Kuparinen, K., \& Heinimö, J. (2013). Large industrial users of energy biomass. IEA Bioenergy Task: Sustainable International Bioenergy Trade, 40, 1-75.

Authors' contributions: IRFG: writing, conceptualization, data curation, formal analysis, methodology; RCS, GBV and GGCS: conceptualization, funding acquisition, supervision; RVOC and SMGR: data curation, formal analysis, methodology; CPSS, SELC, MKAGS and JLPEL: writing, methodology; supervision. 